\title{
DETERMINAN KEPUASAN PELANGGAN PADA PRODUK PERTAMINA LUBRICANTS
}

\author{
Berto Mulia Wibawa, Iwan Vanany, Fakhri Anggara \\ Institut Teknologi Sepuluh Nopember Surabaya \\ berto@mb.its.ac.id, vanany@ie.its.ac.id
}

\begin{abstract}
Lubricant industry is one of the strategic industries in around the world. The potential of the lubricant industry in Indonesia grows rapidly along with the increasing demand and the number of a vehicle from year to year. This study aims to analyze factors that influencing customer satisfaction Pertamina Lubricants product and measure how far the customer satisfaction level of its product. This study observed eight categories of Pertamina Lubricants product, with quota sampling technique where each category of the product taken 30 samples, so the total number of the sample are 240 respondents. Multiple linear regression and customer satisfaction index were used in this study. The study finds brand popularity has the most significant effect on customer satisfaction, followed by price and durability. Customer satisfaction level stands at 78 percent, which means belongs in the satisfied category. Managerial implications of this study provide strategies for Pertamina Lubricants to improve their business performance and to increase the level of customer satisfaction.
\end{abstract}

Keywords: customer satisfaction, multiple linear regression, customer satisfaction index

\begin{abstract}
Abstrak
Industri pelumas merupakan salah satu industri strategis di dunia. Potensi industri pelumas di Indonesia bertumbuh pesat bersamaan dengan meningkatnya permintaan dan jumlah kendaraan bermotor dari tahun ketahun. Penelitian ini bertujuan untuk menganalisis faktorfaktor yang mempengaruhi kepuasan pelanggan produk Pertamina Lubricants dan mengukur sejauh mana tingkat kepuasan pelanggan produk tersebut. Penelitian ini mengamati 8 kategori produk Pertamina Lubricants, dengan teknik pengambilan sampel quota sampling dimana pada setiap kategori produk diambil 30 sampel sehingga jumlah total sampel adalah 240 responden. Analisis regresi linear berganda dan indeks kepuasan pelanggan digunakan dalam penelitian ini. Temuan dalam penelitian ini adalah kepopuleran merek memiliki pengaruh yang paling signifikan terhadap kepuasan pelanggan, diikuti harga dan usia pakai. Tingkat kepuasan pelanggan berada pada angka 78 persen, yang berarti termasuk dalam kategori memuaskan. Implikasi manajerial dari penelitian ini menyediakan strategi bagi Pertamina Lubricants untuk meningkatkan performa bisnis dan tingkat kepuasan pelanggan.
\end{abstract}

Kata kunci : kepuasan pelanggan, regresi linear berganda, indeks kepuasan pelanggan

Diterima: 21 Desember 2016; Direvisi: 26 Januari 2017; Disetujui: 20 Februari 2017 


\section{PENDAHULUAN}

Industri pelumas merupakan salah satu industri strategis di seluruh dunia. Hidayat (2012) mengungkapkan bahwa terdapat lebih dari 200 produsen pelumas tersebar di seluruh wilayah Indonesia. Sebagian besar dari produsen tersebut beroperasi di Pulau Jawa. Dengan jumlah produsen pelumas yang ada membuat kapasitas produksi mecapai 700.000 kilo liter per tahunnya dengan nilai omset diperkirakan lebih dari Rp 7 triliun. Tingginya potensi produksi pelumas ini dapat mendorong ekspor pelumas ke Negara-negara Asia Tenggara, Jepang, Cina, Korea Selatan, Timur Tengah ataupun Uni Eropa. Menurut Toar (2014), permintaan pelumas tumbuh bila dibandingkan tahun 2013, kenaikan penjualan pelumas menyusul peningkatan infrastruktur yang bisa memicu pertumbuhan ekonomi. Konsumsi pelumas mencapai 1,05 juta kilo liter atau tumbuh 5 persen dari tahun 2013.

Pertamina merupakan salah satu produsen pelumas terbesar di Indonesia. PT Pertamina sendiri memiliki anak perusahaan yang khusus berbisnis dibidang pelumas yaitu Pertamina Lubricants. Kinerja Pertamina Lubricants tidak terlepas dari kinerja perusahaan induk yaitu Pertamina. Pada tahun 2014 kinerja Pertamina tidak lepas dari pergerakan harga minyak dunia yang dipengaruhi oleh geopolitik timur tengah, terjadinya penawaran berlebih atas minyak dunia menyebabkan harga rata-rata dari Indonesian Crude Price (ICP) turun menjadi US\$45/barel pada November 2016 (Kementerian ESDM RI, 2016). Kondisi tersebut menekan kinerja perusahaan-perusahaan pada sektor industri migas global, termasuk Pertamina. Untuk mengantisipasi dampak dari penurunan harga minyak, Pertamina beroperasi dan menjalankan strategi perusahaan dengan melakukan berbagai upaya efisiensi dan optimalisasi dari hulu hingga hilir.

Pertamina Lubricants memiliki market share yang terus bertumbuh bahkan menembus angka 60\% hingga pertengahan tahun 2016. Penjualan produk Pertamina Lubricants tersebar di seluruh SPBU di Indonesia yang berjumlah 5200 SPBU, sedangkan untuk distribusi dan pemasaran domestik didukung oleh 3 unit produksi yang berlokasi di Jakarta, Cilacap dan Gresik. Berlakunya MEA 
(Masyarakat Ekonomi Asean) pada akhir 2015 telah memicu persaingan antara pemain utama produsen minyak nasional dan juga internasional. Para produsen minyak nasional maupun internasional berlomba untuk meningkatkan cengkraman di pasar pelumas (Halim, 2016). Berdasarkan data Top Brand Award (2015), produk Pertamina Lubricants tidak termasuk dalam kategori top, sehingga walaupun mendominasi pangsa pasar kesadaran masyarakat terhadap keberadaan, kualitas, dan performa Pertamina Lubricants masih dirasa kurang. Saat ini perlu diakui bahwa berdasarkan persepsi pelanggan, Pertamina Lubricants masih dikenal sebagai produsen pelumas dengan ciri khas ekonomis, bukan pada kualitas terbaik (Anggara, 2016). Terdapat pula sebagian komplain ketidakpuasan pelanggan terhadap kualitas dan usia pakai pelumas Pertamina Lubricants yang dinilai tidak lebih baik dari produk pesaing.

Pertamina Lubricants perlu menyadari bahwa tingkat kepuasan yang tinggi akan berdampak bagi loyalitas dari pelanggan (Kim, dkk, 2004). Kepuasan pelanggan juga merupakan kunci strategi bagi perusahaan yang bersifat jangka panjang terutama dalam hal profitabilitas dan nilai pasar (Gruca \& Rego, 2005). Persaingan yang semakin ketat pada industri pelumas saat ini membuat Pertamina Lubricants harus memahami faktor-faktor apa saja yang mempengaruhi kepuasan pelanggan mereka terhadap produk yang ditawarkan. Selain itu mereka juga harus mengetahui sejauhmana tingkat kepuasan pelanggan saat ini, agar ke depannya bisa lebih kompetitif dan lebih berorientasi kepada pelanggan dalam memasarkan produknya. Penelitian ini bertujuan untuk menganalisis faktor-faktor yang mempengaruhi kepuasan pelanggan produk Pertamina Lubricants dan mengukur sejauh mana tingkat kepuasan pelanggan produk Pertamina Lubricants.

\section{METODE}

Penelitian ini dilakukan pada tiga kota di Jawa Timur yaitu Kota Surabaya, Gresik, dan Sidoarjo. Alasan memilih lokasi penelitian tersebut adalah karena kotakota tersebut memiliki daerah perindustrian dan juga penduduk yang padat. 
Populasi pada penelitian kali ini adalah konsumen atau sektor industri yang menggunakan produk Pertamina Lubricants di daerah Jawa timur. Untuk kriteria sampel adalah konsumen atau sektor industri yang pernah menggunakan produk Pertamina Lubricants minimal selama 1 tahun. Dengan demikian sampel dalam penelitian kali ini adalah para konsumen (end users) maupun sektor industri yang pernah menggunakan produk Pertamina Lubricants minimal 1 tahun di daerah Jawa Timur dan bersedia menjawab pertanyaan yang diajukan oleh peneliti. Teknik pengambilan sampel yang dipilih adalah quota sampling, dimana pada setiap kategori produk diambil 30 sampel sehingga jumlah total sampel adalah 240 responden.

Teknik analisis yang dipergunakan dalam penelitian ini ialah regresi linear berganda. Pada penelitian kali ini variabel dependen adalah kepuasan pelanggan $(\mathrm{Y})$, sedangkan untuk variabel independennya merupakan atribut pelumas yang terdiri dari enam variabel yaitu performa $\left(\mathrm{X}_{1}\right)$, usia pakai $\left(\mathrm{X}_{2}\right)$, kemudahan diperoleh $\left(\mathrm{X}_{3}\right)$, harga $\left(\mathrm{X}_{4}\right)$, Kemasan $\left(\mathrm{X}_{5}\right)$ dan kepopuleran merek $\left(\mathrm{X}_{6}\right)$. Adapun persamaan regresi dalam penelitian ini adalah sebagai berikut:

$$
Y_{i}=\alpha+\beta_{1} X_{1 i}+\beta_{2} X_{2 i}+\beta_{3} X_{3 i}+\beta_{4} X_{4 i}+\beta_{5} X_{5 i}+\beta_{6} X_{6 i}+\varepsilon_{i}
$$

Pengukuran kepuasan pelanggan dalam penelitian ini menggunakan Customer Satisfaction Index (CSI). Untuk memperoleh nilai CSI dapat dihitung dengan menggunakan rumus :

$$
\mathrm{CSI}=\frac{\text { Mean Satisfaction Score }}{\text { Highest Satisfaction Score }} \times 100 \%
$$

Indeks yang telah diperoleh selanjutnya akan dikategorikan dengan interpretasi berdasarkan kategori yang ada. Penggunaan metode ini dapat menunjukkan kategori kepuasan pelanggan Pertamina Lubricants sesuai dengan indeks yang dimiliki (Tabel 1). 
Tabel 1. Interpretasi Customer Satisfaction Index

\begin{tabular}{cc}
\hline Angka Indeks & Interpretasi \\
$\mathrm{X} \leq 20 \%$ & Sangat Tidak Memuaskan \\
$20 \%<\mathrm{X} \leq 40 \%$ & Tidak Puas \\
$40 \%<\mathrm{X} \leq 60 \%$ & Cukup Puas \\
$60 \%<\mathrm{X} \leq 80 \%$ & Puas \\
$80 \%<\mathrm{X}$ & Sangat Memuaskan \\
\hline
\end{tabular}

Sumber: (Wibawa, dkk, 2014)

\section{HASIL DAN PEMBAHASAN}

Hasil

Sebelum masuk ketahap pengolahan dan analisis data lebih lanjut, perlu dilakukan uji outlier. Uji ini bertujuan untuk mengetahui data penelitian yang memiliki karakteristik unik yang terlihat sangat berbeda jauh dari observasiobservasi lainya (Ghozali, 2011). Pada penelitian ini dilakukan pengecekan outlier dengan uji outlier univariate yaitu dengan cara melihat nilai z-score. Untuk data dengan jumlah di atas 80 batas maksimum dan minimum nilai $z$-score adalah \pm 4 (Hair, dkk, 2014). Hasil dari uji outlier menunjukkan bahwa z-score dari seluruh data yang berjumlah 240 tidak ada yang melebihi batas maksimum dan minimum. Hal ini menunjukkan secara univariate tidak ada outlier pada data, sehingga seluruh data bisa diikut sertakan dalam pengolahan data.

Langkah pertama dalam melakukan uji asumsi klasik sebelum masuk ke analisis regresi linear berganda adalah uji normalitas. Uji normalitas menggunakan teknik probability plot dan kolmogorov smirnov untuk memperkuat hasil interpretasi. Hasil probability plot menunjukkan bahwa titik-titik terkumpul dan mengikuti garis lurus, sehingga data bisa disimpulkan mengikuti distribusi normal. Hasil uji kolmogorov smirnov juga menunjukkan hasil signifikan dengan nilai signifikansi sebesar 0.059. Sesuai dengan pernyataan Lilliefors (1967), jika nilai signifikansi dari uji kolmogorov smirnov > 0,05 ( $\alpha=5 \%)$, maka residual model dari regresi sudah terdistribusi secara normal. Langkah kedua adalah melakukan uji linearitas untuk melihat apakah spesifikasi model yang digunakan sudah benar atau tidak (Ghozali, 2011). Uji linearitas menggunakan matriks scatter plot yang melibatkan seluruh variabel penelitian. Hasil dari matriks scatter plot menunjukkan bahwa hubungan antar variabel secara keseluruhan memiliki sifat yang linear. 
Langkah ketiga adalah melakukan uji multikolinearitas untuk mengetahui bilamana terdapat korelasi yang tinggi antara variabel-variabel independennya. Uji multikolinearitas sendiri memiliki 2 acuan, yaitu berdasarkan nilai toleransi dimana nilai toleransi harus memenuhi $>0,10$ dan acuan lainnya adalah melihat nilai Variance Inflation Factor (VIF) yang muncul harus memenuhi <10, maka bisa dikatakan model yang akan dianalisis bebas dari multikolinearitas. Nilai toleransi diketahui berkisar antara 0,458 sampai dengan 0,651, yang berarti seluruh variabel telah memenuhi acuan nilai toleransi $>0,10$. Sedangkan nilai VIF seluruhnya berada $<10$, yang berarti model telah memenuhi persyaratan lolos uji multikolinearitas karena tidak terdapat hubungan atau kesamaan yang berarti antar variabel independen (Tabel 5).

Langkah terakhir adalah melakukan uji homoskedastisitas untuk mencari tahu apakah data yang digunakan pada penelitian ini bersifat homogen. Menurut Ghozali (2011) model regresi yang baik adalah model yang homoskedastisitas atau tidak terjadi heteroskedastisitas. Untuk menguji homoskedatisitas persamaan regresi dilihat dengan persebaran titik scatterplot. Jika scatterplot menghasilkan titik-titik yang menyebar di atas dan di bawah angka nol pada sumbu Y, maka dapat disimpulkan tidak terjadi heteroskedastisitas pada model regresi (Hasanah, 2008). Hasil scatterplot menunjukkan bahwa terdapat titiktitik yang menyebar sesuai dengan ketentuan homoskedastisitas.

Tabel 2. Uji Multikolinieritas

\begin{tabular}{lccc}
\hline \multicolumn{1}{c}{ Variabel } & \multicolumn{2}{c}{ Colinierity Statistics } & \multirow{2}{*}{ Keterangan } \\
& Toleransi & VIF & Non-multikolinieritas \\
& 0.562 & 1.855 & Non-multikolinieritas \\
Performa & 0.577 & 1.811 & Non-multikolinieritas \\
Ksia pakai & 0.472 & 2.245 & Non-multikolinieritas \\
Harga & 0.478 & 2.175 & Non-multikolinieritas \\
Kemasan & 0.622 & 1.666 & Non-multikolinieritas \\
Kepopuleran & 0.681 & 1.539 & \\
\hline
\end{tabular}

Analisis regresi linear berganda dilakukan untuk mengetahui faktorfaktor yang memiliki pengaruh ataupun kontribusi terkuat dalam terciptanya kepuasan pelanggan produk Pertamina Lubricants. Penghitungan nilai beta, $\mathrm{t}$ hitung, dan signifikansi selengkapnya ditampilkan pada Tabel 3. 
Tabel 3. Analisis Regresi Linier Berganda

\begin{tabular}{lcccc}
\hline \multicolumn{1}{c}{ Model } & Koefisien & $\boldsymbol{\beta}$ & t hitung & Signifikansi \\
\hline Konstanta & 0.009 & & 0.510 & 0.951 \\
Performa (X1) & 0.102 & 0.101 & 2.630 & 0.009 \\
Usia pakai (X2) & 0.178 & 0.225 & 5.046 & 0.000 \\
Kemudahan diperoleh (X3) & 0.155 & 0.157 & 3.422 & 0.000 \\
Harga (X4) & 0.242 & 0.233 & 5.021 & 0.000 \\
Kemasan (X5) & 0.135 & 0.145 & 3.620 & 0.000 \\
Kepopuleran merek (X6) & 0.249 & 0.259 & 6.831 & 0.000 \\
\hline
\end{tabular}

Diperoleh persamaan regresi linear berganda untuk 6 variabel independen terhadap variabel dependen sebagai berikut :

$$
Y=0,009+0,102 X_{1}+0,178 X_{2}+0,155 X_{3}+0,242 X_{4}+0,135 X_{5}+0,249 X_{6}
$$

Bila dilihat dari nilai koefisien regresi pada persamaan diatas, diketahui bahwa seluruh koefisien variabel bernilai positif. Artinya seluruh variabel memiliki pengaruh positif terhadap variabel dependennya. Variabel kepopuleran merek memiliki nilai beta tertinggi diantara keenam variabel lainnya $(\beta=0.259)$. Artinya variabel kepopuleran merek merupakan variabel yang paling berpengaruh dan berkontribusi terhadap kepuasan pelanggan produk Pertamina Lubricants. Interprentasi nilai beta tersebut adalah apabila variabel kepopuleran merek meningkat sebesar 1 , dengan asumsi kelima variabel lainnya konstan, maka akan meningkatkan kepuasan pelanggan sebesar 0,249. Variabel dengan nilai beta tertinggi kedua dan ketiga adalah harga dan usia pakai. Adapun variabel dengan nilai beta tertinggi keempat, kelima, dan keenam secara berturut turut adalah kemudahan diperoleh, kemasan, dan performa.

Pada output regresi linear berganda diperoleh nilai $\mathrm{R}$ sebesar 0.851 , sehingga dapat dikatakan hubungan antara keenam variabel independen dengan variabel dependen sangat kuat. Nilai $\mathrm{R}^{2}$ atau koefisien determinasi yang diperoleh sebesar 0.757, nilai ini memiliki arti bahwa kemampuan variabel-variabel independen dalam menjelaskan variasi perubahan variabel dependen adalah sebesar 75.7 persen, dimana sisanya sebesar 24.3 persen dijelaskan oleh faktor lain yang tidak termasuk kedalam penelitian ini (Ghozali, 2011). Terkait dengan nilai signifikansi, seluruh variabel diketahui memiliki nilai signifikansi dibawah $<0,05$ $(\alpha=5 \%)$, yang berarti seluruh variabel independen terbukti memiliki pengaruh yang 
signifikan terhadap variabel dependen.

Pembahasan

Hipotesis pertama diterima dan terbukti, dimana performa pelumas berpengaruh positif signifikan terhadap kepuasan pelanggan Pertamina Lubricants. Hal ini diperkuat dengan analisa statistik yang menunjukkan nilai signifikansi variabel performa. Nilai signifikansi performa pada output regresi menunjukkan nilai 0.009 , nilai tersebut telah memenuhi syarat berada dibawah nilai cut-off sebesar $0.05(\alpha=5 \%)$ (Hair, dkk, 2014). Dengan perolehan nilai koefisien regresi 0.102 menunjukkan bahwa pengaruh dari performa bersifat positif. Jadi semakin baik performa dari pelumas akan semakin meningkatkan nilai kepuasan pelanggan.

Performa oli merupakan salah satu alasan baik atau tidaknya kinerja sebuah mesin, baik mesin untuk kendaraan bermotor maupun peralatan industri. Performa oli yang baik mampu menjaga keawetan mesin, performa operasional harian mesin, dan mampu merawat mesin. Kepuasan pelanggan tercipta karena performa oli yang baik. Dalam penelitian ini, nilai beta dari variabel performa (0.109) berada pada posisi terakhir dan memiliki nilai terendah dari variabel pembentuk kepuasan pelanggan. Hal ini menunjukkan bahwa terdapat peran performa dalam menciptakan kepuasan pelanggan produk Pertamina Lubricants, tetapi masih kalah dengan variabel lain yang menjadi amatan. Pelanggan masih menganggap pelumas keluaran Pertamina Lubricants masih memiliki performa dibawah pelumas merek lain, terutama pelumas dengan reputasi internasional. Persepsi harga pelumas Pertamina Lubricants yang murah diduga menjadi salah satu faktor pemicu rendahnya penilaian performa pelumas oleh pelanggan, sehingga menghasilkan kepuasan yang paling rendah jika dibandingkan dengan faktor lainnya. Padahal konsumen hanya menilai berdasarkan persepsi dan pengalaman, bukan melalui kajian ilmiah yang memang dapat membuktikan sejauhmana performa pelumas antar merek.

Hipotesis kedua diterima dan terbukti, dimana usia pakai pelumas berpengaruh positif signifikan terhadap kepuasan pelanggan Pertamina Lubricants. Hal ini diperkuat dengan analisa statistik yang menunjukkan nilai signifikansi 
variabel usia pakai. Nilai signifikansi usia pakai pada output regresi menunjukkan nilai 0.000 , nilai tersebut telah memenuhi syarat berada dibawah nilai cut-off sebesar $0.05(\alpha=5 \%)$ (Hair, dkk, 2014). Dengan perolehan nilai koefisien regresi 0,178 menunjukkan bahwa pengaruh dari usia pakai bersifat positif. Jadi semakin lama usia pemakaian dari oli Pertamina Lubricants akan meningkatkan nilai dari kepuasan pelanggan.

Sama seperti performa, usia pakai merupakan bagian dari kualitas produk. Usia pakai atau durability menunjukkan suatu pengukuran terhadap siklus produk, baik secara teknis maupun waktu (Irawan, 2008). Usia pakai pelumas keluaran Pertamina Lubricants mampu berkontribusi sebagai variabel terpenting ketiga sebagai faktor yang mempengaruhi kepuasan pelanggan. Dalam rangka meningkatkan kepuasan pelanggan, Pertamina Lubricants dapat mempertimbangkan untuk meluncurkan pelumas yang memiliki usia pakai lebih lama dari rata-rata yang ditawarkan kompetitor. Dewasa ini konsumen sangat tertarik dengan efisiensi pelumas, sehingga bisa tetap memberikan perlindungan terhadap mesin sambil menghemat pengeluaran untuk pelumas.

Hipotesis ketiga diterima dan terbukti, kemudahan diperoleh berpengaruh positif signifikan terhadap kepuasan pelanggan Pertamina Lubricants. Hal ini diperkuat dengan analisa statistik yang menunjukkan nilai signifikansi variabel usia pakai. Nilai signifikansi kemudahan diperoleh pada output regresi menunjukkan nilai 0.000 , nilai tersebut telah memenuhi syarat berada dibawah nilai cut-off sebesar $0.05(\alpha=5 \%)$ (Hair, dkk, 2014). Dengan perolehan nilai koefisien regresi 0.155 menunjukkan bahwa pengaruh dari kemudahan diperoleh bersifat positif. Jadi semakin mudah didapatkannya produk Pertamina Lubricants akan meningkatkan nilai dari kepuasan pelanggan.

Produk Pertamina Lubricants memiliki keunggulan dalam pemasaran produknya karena bekerjasama secara langsung dengan ritel Stasiun Pengisian Bahan Bakar Umum (SPBU) resmi Pertamina yang tersebar di seluruh Indonesia. Salah satu alasan Pertamina Lubricants menjadi pemimpin pasar pelumas adalah karena didukung penuh oleh PT. Pertamina selaku induk 
perusahaan dan juga pemerintah. Jika dibandingkan dengan kompetitor, pelumas Pertamina Lubricants masih tergolong lebih mudah didapatkan karena memiliki sistem distribusi dan daya jangkau produk hingga pelosok Indonesia. Untuk produk pelumas khusus industri, Pertamina Lubricants juga menjalin kerjasama dengan agen-agen resmi reseller dalam memasarkan produknya. Dengan sistem permasaran yang baik, perusahaan manapun tinggal melakukan pemesanan dan nantinya produk akan dikirim via ekspedisi ataupun diantar langsung oleh perwakilan produsen. Tetapi hal yang melemahkan keberadaan produk Pertamina Lubricants adalah sulit didapat di ritel pelumas atau bengkel modern, yang kebanyakan memasarkan produk yang lebih ternama dengan kualitas yang lebih baik. Hal ini diduga menjadi alasan bahwa variabel kemudahan diperoleh hanya memiliki kontribusi terbesar keempat jika dibandingkan dengan variabel lain pembentuk variabel kepuasan pelanggan.

Hipotesis keempat diterima dan terbukti, harga ternyata berpengaruh positif signifikan terhadap kepuasan pelanggan Pertamina Lubricants. Hal ini diperkuat dengan analisa statistik yang menunjukkan nilai signifikansi variabel harga. Nilai signifikansi harga pada output regresi menunjukkan nilai 0,000, yang berarti berada dibawah nilai cut-off sebesar 0.05 ( $\alpha=5 \%$ ) (Hair, dkk, 2014). Dengan perolehan nilai koefisien regresi 0.242 menunjukkan bahwa pengaruh dari harga bersifat positif. Jadi semakin baik harga yang ditawarkan Pertamina Lubricants akan meningkatkan nilai dari kepuasan pelanggan.

Konsumen sering memandang harga sebagai indikator nilai dan sering dihubungan dengan kepuasan pelanggan atas suatu barang dan jasa. Produk yang mempunyai kualitas yang sama, namun memiliki penawaran harga yang lebih baik akan memberikan nilai yang lebih tinggi kepada pelanggan (Kotler \& Keller, 2012). Saat ini harga produk Pertamina Lubricants berada dibawah rata-rata harga yang ditawarkan kompetitor. Aspek ekonomis kemudian menjadi ciri utama pelumas Pertamina Lubricants dalam benak pelanggan. Dengan profil demografi pelanggan Indonesia saat ini yang belum berpenghasilan cukup tinggi, maka sebenarnya strategi harga yang diterapkan Pertamina Lubricants sudah 
tepat. Harga yang ekonomis, baik dari persepsi pelanggan saat ini maupun perwakilan responden perusahaan mampu membawa variabel ini memiliki kontribusi kedua tertinggi sebagai pembentuk variabel kepuasan pelanggan, yang berarti bahwa kepuasan pelanggan timbul sebagai akibat dari harga yang ditawarkan kepada pelanggan.

Hipotesis kelima diterima dan terbukti, kemasan berpengaruh positif signifikan terhadap kepuasan pelanggan Pertamina Lubricants. Hal ini diperkuat dengan analisa statistik yang menunjukkan nilai signifikansi variabel kemasan. Nilai signifikansi kemasan pada output regresi menunjukkan nilai 0.000 , yang berarti berada dibawah nilai cut-off sebesar 0.05 ( $\alpha=5 \%)$ (Hair, dkk, 2014). Dengan perolehan nilai koefisien regresi 0.135 menunjukkan bahwa pengaruh dari kemasan bersifat positif. Semakin baik kemasan produk Pertamina Lubricants akan meningkatkan nilai dari kepuasan pelanggan.

Desain kemasan pelumas merepresentasikan fitur, keandalan, dan identitas dari produk. Dewasa ini desain kemasan memiliki peran yang cukup penting dalam menarik pelanggan. Dalam penelitian ini variabel kemasan memiliki kontribusi kelima tertinggi sebagai pembentuk variabel kepuasan pelanggan. Hal ini disebabkan dalam kondisi sebenarnya, produk Pertamina Lubricants dinilai oleh pelanggan kurang memiliki ciri khas dan identitas yang menarik. Berbeda dengan merek pelumas multinasional lainnya yang sudah memiliki ciri khas kemasan yang mudah dikenali oleh pelanggan. Warna dominan merah pada desain kemasan dinilai belum cukup untuk mencirikan produk Pertamina Lubricants, karena cenderung bersaing dengan kompetitor yang juga mengandalkan warna merah. Selain itu untuk skala industri, terutama industri yang sudah sangat besar, produk Pertamina Lubricants biasanya diecer dalam jumlah yang banyak hanya dengan menggunakan drum polos berwarna merah, yang kemudian distempel dengan logo Pertamina Lubricants. Perlu dilakukan revisi strategi pemasaran dalam menyampaikan produk kepada industri dalam skala besar. Pembelian skala besar bukan berarti mengabaikan desain kemasan, tetapi harus bisa lebih berkreasi menciptakan sebuah wadah besar yang penuh dengan identitas, unik, dan mudah diingat oleh pelanggan. Selain desain yang menarik, keamanan isi produk juga tetap perlu 
diperhatikan.

Hipotesis keenam diterima dan terbukti, kepopuleran ternyata berpengaruh positif signifikan terhadap kepuasan pelanggan para konsumen Pertamina Lubricants. Hal ini diperkuat dengan analisa statistik yang menunjukkan nilai signifikansi variabel kepopuleran merek. Nilai signifikansi kepopuleren merek pada output regresi menunjukkan nilai 0.000 , nilai tersebut telah memenuhi syratat berada dibawah nilai cut-off sebesar $0.05(\alpha=5 \%)$ (Hair, dkk, 2014). Kepopuleran merek berpengaruh signifikan terhadap kepuasan pelanggan. Dengan perolehan nilai koefisien regresi 0.249 menunjukkan bahwa pengaruh dari kepopuleran merek bersifat positif. Jadi semakin populer produk Pertamina Lubricants akan meningkatkan nilai dari kepuasan pelanggan.

Kepopuleran merek Pertamina Lubricants berawal dari kata pertama yaitu "Pertamina", yang notabene dikenal sebagai satu-satunya perusahaan milik negara yang ditugaskan melaksanakan bisnis minyak dan gas di seluruh wilayah Indonesia. Pertamina memiliki brand awareness yang tinggi karena identik dengan SPBU terbesar yang memiliki cabang di seluruh wilayah di Indonesia, sehingga dapat mudah dikenali. Pertamina Lubricants, memiliki kepopuleran merek karena merupakan anak perusahaan dari PT. Pertamina (Persero), dimana hampir semua orang di Indonesia mengenal perusahaan tersebut. Wajar saja jika pelanggan dapat langsung merasa familiar terhadap sebuah merek yang mengandung kata "Pertamina", dan langsung memiliki persepsi yang baik seiring dengan pelayanan yang diberikan pada bisnis bahan bakar yang telah mereka rasakan sejak lama. Variabel kepopuleran merek memiliki kontribusi tertinggi dalam pembentukan variabel kepuasan pelanggan, hal ini berarti kepuasan pelanggan tercipta utamanya oleh kepopuleran merek. Hal ini sebenarnya kontradiktif karena kepopuleran merek berbanding terbalik dengan performa pelumas, yang memiliki kontribusi terendah dalam pembentukan kepuasan pelanggan. Hasil penelitian menunjukkan bahwa responden menganggap kepopuleran merek dapat lebih memuaskan mereka dibandingkan dengan performa atau usia pakai pelumas, hal ini dinilai cukup menarik dan menjadi temuan utama dalam penelitian ini.

Analisis kepuasan pelanggan diukur dengan menggunakan 3 indikator, 
yaitu kepuasan terhadap kualitas, manfaat, dan keseluruhan produk. Hasil penelitian menunjukkan bahwa nilai CSI pada produk Pertamina Lubricants secara keseluruhan adalah 78 persen, yang berarti kepuasan konsumen berada pada tingkat "puas". Hasil ini dinilai sudah belum maksimal karena tingkat kepuasan pelanggan belum sampai pada tingkat "sangat memuaskan". Hal ini dapat menjadi masalah ketika tingkat kepuasan pelanggan tidak mampu ditingkatkan oleh Pertamina Lubricants. Diperlukan sebuah rencana tindakan oleh Pertamina Lubricants untuk melakukan evaluasi pemasaran produk terutama dari tiga variabel utama pembentuk kepuasan pelanggan yaitu kepopuleran merek, harga, dan usia pakai.

Pertamina Lubricants sebagai salah satu anak perusahaan PT Pertamina yang bergerak dibidang energi dibentuk untuk meningkatkan kekuatan bisnis pada bidang usaha pelumas. Pertamina Lubricants memiliki target capaian sebagai Wolrd Lubricants Company. Sebelum dapat mencapai hal tersebut terlebih dahulu Pertamina Lubricants harus bisa menguasai pasar pelumas dalam negeri. Sebelum tahun 2001 Pertamina merupakan perusahaan yang melakukan monopoli terhadap pasar pelumas Indonesia dan menguasai pangsa pasar hingga $90 \%$. Namun setelah ditetapkannya Kepres No.21/2001 yang mencabut hak monopoli Pertamina, pangsa pasar Pertamina sendiri mengalami penurunan. Hingga saat ini pangsa pasar Pertamina sendiri berada pada angka 60\%. Banyaknya pemain baru di pasar pelumas Indonesia membuat persaingan semakin ketat. Apalagi ditambah dengan berlakunya Masyarakat Ekonomi Asean (MEA) pada tahun 2015 yang dapat menyebabkan banyaknya pemain asing masuk ke dalam pasar pelumas Indonesia.

Selain faktor-faktor di atas, kualitas layanan perlu pula menjadi perhatian bagi PT Pertamina dalam pemasaran pelumasnya. Hal ini sesuai dengan penelitian yang dilakukan Wijayanto (2015); Krisnawati (2016). Implikasi manajerial selengkapnya dijelaskan pada Tabel 4. 
Tabel 4. Implikasi Manajerial

\begin{tabular}{|c|c|}
\hline el & Rekomendasi Strategi \\
\hline Har & $\begin{array}{l}\text { 1. Mempertahankan harga yang sudah ada dengan peningkatan dalam } \\
\text { fitur desain kemasan yang lebih menarik dan penjelasan deskriptif } \\
\text { mengenai fitur performa yang menyatakan bahwa kualitas pelumas } \\
\text { Pertamina Lubricants tidak kalah jika dibandingkan dengan kompetitor. } \\
\text { 2. Menerapkan strategi cost leadership dan memenangkan persaingan } \\
\text { dengan menawarkan harga yang paling menarik dibandingkan dengan } \\
\text { kompetitor. } \\
\text { 3. Merumuskan strategi penetapan harga yang kreatif, dengan promosi } \\
\text { produk bundling dengan produk Pertamina lainnya. } \\
\text { 4. Bekerja sama dengan bengkel-bengkel untuk mengadakan promo- } \\
\text { promo untuk setiap pembelian atau melakukan penggantian pelumas } \\
\text { keluaran Pertamina Lubricants. } \\
\text { 5. Memberikan harga spesial bagi perusahaan yang menjalin kontrak } \\
\text { jangka panjang minimal } 5 \text { tahun dan menetapkan Pertamina Lubricants } \\
\text { sebagai supplier pelumas utama. }\end{array}$ \\
\hline Usia & $\begin{array}{l}\text { 1. Melakukan pengembangan produk melalui kerjasama riset dengan } \\
\text { pihak perguruan tinggi untuk menghasilkan varian produk pelumas } \\
\text { baru yang lebih tahan lama dan efisien. } \\
\text { 2. Memperbanyak edukasi kepada pelanggan bahwa usia pakai pelumas } \\
\text { keluaran Pertamina Lubricants setara dengan pelumas multinasional } \\
\text { lainnya. } \\
\text { 3. Memberikan tips dan trik kepada pelanggan terkait cara } \\
\text { memaksimalkan usia pakai pelumas dalam kaitannya dengan } \\
\text { penggunaan mesin kendaraan ataupun mesin pabrik. }\end{array}$ \\
\hline $\begin{array}{l}\text { Kepopu } \\
\text { Merek }\end{array}$ & $\begin{array}{l}\text { 1. Memperbanyak peran sebagai sponsor untuk event otomotif skala } \\
\text { nasional maupun internasional dalam rangka meningkatkan } \\
\text { popularitas merek Pertamina Lubricants.. } \\
\text { 2. Rutin mengadakan social gathering dengan para loyalis produk } \\
\text { Pertamina Lubricants, terutama segmen pelanggan produk premium. } \\
\text { 3. Membuat jingle Pertamina Lubricants dengan tujuan meningkatkan } \\
\text { brand awareness masyarakat yang disertakan dalam setiap aktivitas } \\
\text { iklan di media elektronik. } \\
\text { 4. Memberikan voucher promo atau reward bagi para followers } \\
\text { Pertamina Lubricants di media sosial. }\end{array}$ \\
\hline
\end{tabular}

\section{Simpulan}

Berdasarkan hasil penelitian, diketahui variabel kepopuleran merek, harga dan usia pakai dari produk Pertamina Lubricants memiliki pengaruh dan kontribusi pembentuk paling besar terhadap kepuasan pelanggan. Pihak Pertamina Lubricants direkomendasika agar lebih memperhatikan aspek-aspek yang berhubungan dengan ketiga variabel tersebut dalam rangka meningkatkan kepuasan pelanggan yang masih berada angka 78 persen, yang berarti tingkat kepuasan masih 
tergolong kedalam kategori "puas", belum sampai "sangat puas". Diperlukan strategi khusus meningkatkan kepuasan pelanggan Pertamina Lubricants, dimana fokus strategi berdasarkan ketiga variabel tertinggi pembentuk dimensi kepuasan pelanggan yaitu kepopuleran merk, harga, dan usia pakai.

Saran bagi pihak Pertamina Lubricants adalah melakukan pengukuran kepuasan pelanggan dengan menggunakan sampel dan cakupan wilayah yang lebih besar, agar bisa mendapatkan data yang lebih representatif. Selain itu pengukuran tingkat kepuasan sebaiknya dilakukan secara berkala setiap 1 tahun sekali, dengan tujuan mengetahui pergerakan tingkat kepuasan pelanggan setiap tahunnya. Penelitian selanjutnya direkomendasikan untuk menganalisis pola pengambilan keputusan pembelian produk pelumas dan juga loyalitas pelanggan. Sejauh ini belum diketahui faktor apakah yang menjadi pertimbangan utama dalam pengambilan keputusan pembelian produk pelumas, baik kategori pelanggan akhir (end user) ataupun pelanggan industri. Belum diketahui apa faktor pemicu utama terhadap pelanggan yang melakukan pembelian ulang pada produk Pertamina Lubrincants.

\section{PUSTAKA ACUAN}

Anggara, F. (2016). Analisis Strategi Positioning Merek Berdasarkan Preferensi, Persepsi, dan Kepuasan Konsumen Produk Pertamina Lubricants. [skripsi tidak dipublikasikan]. Surabaya: Institut Teknologi Sepuluh Nopember.

Gruca, T. S. \& L.L. Rego. (2005). Customer satisfaction, cash flow, and shareholder value. Journal of Marketing. Vol. 69 (3): 115-130.

Ghozali, I. (2011). Aplikasi Analisis Multivariate Dengan Program IBM SPSS 19 (Edisi Kelima). Semarang: Universitas Diponegoro.

Hair, J. F. dkk. (2014). Multivariate Data Analysis. (7th ed). New Jersey : Pearson Prentice-Hall.

Halim, D. (2016). MEA, Pertajam Persaingan Industri Pelumas Domestik (Online). (http://publik.bumn.go.id/pertamina/berita/8302/MEA.Pertajam.Persaing an.Industri.Pelumas.Domestik diakses pada 7 April 2016).

Hidayat. (2012). Industri Pelumas Tumbuh Pesat. (Online). (http://www.kemenperin.go.id/artikel/7108/Industri-Pelumas-Tumbuh 
diakses pada 11 Agustus 2016).

Irawan. (2008). Manajemen Pemasaran Modern. Yogyakarta: Liberty

Kementerian ESDM RI. (2016). Harga Minyak Mentah Indonesia (IC) Rata-Rata (Online). (http://kip.esdm.go.id/pusdatin/index.php/data-informasi/dataenergi/minyak-dan-gas-bumi/harga-minyak-mentah-icp diakses pada 10 Nopember 2016).

Kim, M. K. dll. (2004). The Effects of customer satisfaction and switching barrier on customer loyalty in Korean mobile telecomunication services. Journal of Telecommunications Policy. Vol 5 (28): 145-159.

Kotler, P. \& K.L Keller. (2012). Marketing Management (14th ed.). New Jersey: Pearson Prentice Hall.

Krisnawati, S.N. (2016). Analisis Pengaruh Kualitas Pelayanan Terhadap Kepuasan Pelanggan SPBU No. 64.751.15. Jurnal Administrasi Bisnis. Vol. 4 (1): 222236.

Lilliefors, H. W. (1967). On the Kolmogorov-Smirnov Test for Normality with Mean and Variance Unknown. Journal of the American Statistical Association. Vol. 62 (318): 399-402.

Ridha, M. (2005). Analisis Strategi Positioning Pelumas Mesran. [tesis]. Program Magister Manajemen Agribisnis, Institut Pertanian Bogor.

Toar, P. (2014). Tahun Ini Pelumas Tumbuh 5 Persen. (Online). (http://www.pertaminaracing.com/berita/11/5456/others/Tahun+Ini+Pe lumas+Tumbuh+5+Persen diakses pada 13 Februari 2016).

Top Brand Award. (2015). Top Brand Fase 12015 Kategori : Otomotif. (Online). (http://www.topbrand-award.com/top-brand-survey/surveyresult/top_brand_index_2015_fase_1 diakses pada 13 Februari 2016).

Wibawa, B.M. dkk. (2014). Customer satisfaction analysis for HydroVac Vaccine (Case study on catfish farmers in Kabupaten Bogor). International Journal of Business and Management. Vol. 2(11):1-9.

Wijayanto, K. (2015). Pengaruh Kualitas Pelayanan Terhadap Kepuasan dan Loyalitas Nasabah Bank. Daya Saing: Jurnal Ekonomi Manajemen Sumber Daya. Vol. 17, No. 1: 38-45. 